\title{
Towards a Full-Fledged Value-Added Taxation in Egypt
}

\author{
Abdelmonem Lotfy Mohamed ${ }^{1}$ \\ ${ }^{1}$ Department of Economics, Faculty of Economic Studies and Political Science, Beni Suef University, Egypt \\ Correspondence: Abdelmonem Lotfy Mohamed, Faculty of Economic Studies and Political Science, Beni Suef \\ University, Beni Suef, Egypt. Tel: 20-12-7662-9000. E-mail: aLotfy@eps.bsu.edu.eg \\ Received: March 17, 2014 \\ Accepted: April 11, 2014 \\ Online Published: June 25, 2014 \\ doi:10.5539/ijef.v6n7p213 \\ URL: http://dx.doi.org/10.5539/ijef.v6n7p213
}

\begin{abstract}
Since July 2004, the Egyptian governments have tended to continue its economic reform program with targets for increasing economic growth and promoting employment level. One of the main pillars of this economic reform is the fiscal policy reform. Consequently, the Egyptian Ministry of Finance is aiming to modernize the tax system; one of the important steps is to replace the Value Added Tax (VAT) system instead of the current Egyptian Sales Tax (EST).

Therefore, the study discusses the structure of the Sales Tax in Egypt that causes crucial problems such as economic distortions, tax cascading, and inequity of the tax system resulting from excluding several activities, especially in services, from the Sales Tax. Consequently, the first step to implement VAT in Egypt is to calculate the VAT base. Thus, the study chooses to calculate the VAT base using both production and consumption methods.

The results seem to be significant and reasonable with a small difference in estimations between the two methods reaching only $2.9 \%$ of GDP according to data for the fiscal year 2006/2007. Finally, the study recommends the new VAT system to use the consumption-type VAT based on the destination principle and using the invoice credit method and to have $8 \%$ standard rate, instead of $10 \%$ under EST.
\end{abstract}

Keywords: consumption method, Egypt, production method, Value Added Tax (VAT) base

\section{Introduction}

In February 2014, a new government was appointed in Egypt with a mission to accelerate economic reforms in order to boost economic growth and decrease unemployment rate. The new cabinet chose a path for economic growth through improving the investment climate. Several challenges were on the track to enhance the Egyptian competitive position with regard to attracting new investments. Among these challenges, tax reform was on the top. The Egyptian government philosophy was that initiating tax laws closer to international practice would increase the competitiveness of the Egyptian economy.

From economic perspective, modernizing tax laws means that every business faces the same tax burden with no exemptions, tax holidays, or special treatments for large or foreign businesses. On the same road, the Ministry of Finance philosophy for tax reform appeared in reducing the tax rates and widening of the tax base, clear rules for filing and severe punishment for noncompliance. Moreover, measures have been taken to obtain effective tax collection and tax refund methods and effective tax appeals process to ensure the protection of the taxpayers' rights.

The Egyptian tax authority put three goals for the tax reform. The first Goal is to increase tax revenues; the second is to make the tax administration more transparent and fair; and the third is to improve economic performance.

Recently, the Egyptian Ministry of Finance began its bold tax reform through initiating a new Income Tax Law to replace the old one. Therefore, in June 2005 the Egyptian Parliament approved the Law 91/2005 that the Egyptian Ministry of Finance submitted to be a new Income Tax Law. This new law aims to attract additional investment and reduce the scope for tax evasion by the black economy through lower tax rates, limited incentives and improved tax administration.

According to the new law, tax rates were reduced by 50 percent and better tax administration has taken its place. Despite this tax cut, total and income tax revenues climbed from 71.2 and 28.9 billion LE in June 2005 to 98 and 
48.5 billion LE in June 2006, to 114.3 and 58.5 billion LE in June 2007 and to 137.4 and 67 billion LE in June 2008 respectively.

Moreover, total tax revenues as a percentage of GDP has improved clearly during the fiscal years 2004/2005 to 2008/2009. It climbed from 13.2 percent in 2004/2005 to 15.9 percent in 2005/2006 and to stabilize on the level 15.3 percent in fiscal years 2006/2007 and 2007/2008. Then, this percentage climbed again during the fiscal year 2008/2009 to reach 15.7 percent. However, this percentage witnessed a trend of decrease during the fiscal years $2009 / 2010$ to $2011 / 2012$ where it decreased to 14.1 percent in 2009/2010, to 14 percent in 2010/2011 and to 13.2 percent in 2011/2012 reflecting the need for more tax reforms.

In addition, Egypt's economic growth raised from 4.5 percent in 2004/2005, to 6.8 percent in $2005 / 2006$, to 7.1 percent in 2006/2007 and to 7.2 percent in 2007/2008. Also, unemployment rate decreased from 10.47 percent in 2003/2004 to 9.08 percent 2006/2007 implying that tax reform enhanced investment and increased employment.

Because of the deep and quick political changes starting January 2011, GDP growth rates deteriorated to 1.8 percent in 2010/2011, to 2.2 percent in 2011/2012 and to 2.1 percent in 2012/2013. Consequently, the need for more fiscal reforms increased rapidley in front of the current Egyptian government.

From this perspective, the new Egyptian government finds the current situation is suitable to continue reforming the tax system. One of the cornerstone reforms would be introducing the Value Added Tax (VAT) system to replace the Sales Tax system. This paper is trying to discuss the reasons towards implementing VAT in Egypt and how the Egyptian Ministry of Finance can constitute the most appropriate VAT system for Egypt through calculating the potential VAT base in Egypt. Then, the study will provide policy recommendation to the Egyptian Ministry of Finance to implement VAT successfully.

Therefore, in its first part, the study begins with discussing problems with the Egyptian Sales Tax (EST) system, the second is to describe the way to initiate VAT in Egypt, the third presents the definition and design of the VAT, the fourth states the aim of this study and its research questions, the fifth illustrates the literature review and previous trials to calculate the VAT base in other countries, the sixth discusses different methodologies to calculate the VAT base, the seventh shows the theoretical equivalence of both production and consumption methods for calculating the VAT base, the eighth presents applying the production method to Egypt, the ninth presents applying the consumption method to Egypt, the tenth presents conclusion, and finally the study ends with the eleventh section that provides some technical policy recommendations to Egyptian policymakers in designing VAT.

\subsection{Problems with EST System}

Taxing some goods and services and excluding the rest is considered unfair in the modern tax systems. In addition, this unfair system creates economic distortions since it raises prices of goods and services taxed while the rest does not suffer from this problem. It directs investments into untaxed goods and services; therefore, the current system is inefficient since it is biased against the taxed sectors. Moreover, it creates tax cascading as described previously.

Therefore, applying VAT, because of its broad based, will reduce the distortions, inequity of tax burden, and tax cascading occurred in the Egyptian economy as a result for the EST discriminations in applying it on some goods and services and not applying it on the others.

\subsection{The Way to Value Added Tax (VAT) in Egypt}

These positive signs, previously described, resulted from reforming the income tax system gave the Egyptian government incentives towards more reforms. Consequently, Ministry of Finance reformed the Stamp Duties law and preparations have been done to implement a fully fledged Value Added Tax (VAT) system instead of the current Egyptian Sales Tax (EST) system. Recently, the need for initiating VAT in Egypt increased since the Sales Tax system is shown to be complicated, unfair, and inefficient which cause several economic distortions. For more details, the current EST law is written in a positive way that shows the taxable goods and services (presented in tables 1, 2, A, and F in the sales tax law). In addition, table c presents the exempt goods from the tax.

Therefore, in EST system, the tax is not applied on all goods and services. For example, EST is not levied on several activities such as advertising, legal services, private education, Medical Care, writers, athletes, movie directors, certified tax accountants, certified public accountants, and professional players. 
In addition, most of vital services are not taxed under EST; Construction and Building sector is a clear example for this. Moreover, imported services are not taxed under the EST system which gives them an advantage on the Egyptian companies that provide services even in the domestic market.

Also, activities such as the use of inventory or other assets used for business purposes, gift assets by a corporation to its directors, asset transfers made as payment in substitute, successions of loans and other monetary claims excluding general successions, sales of assets which mean transfers to third parties of assets without modifying their identity and without regard to the mode of these transfers, transfers of assets made for the fulfillment of guarantee obligations owed on behalf of third parties or the realization of assets made per procedures for compulsory conversions, and leasing of assets which includes any and all acts made for the creation of rights pertaining to assets and permitting their use by other parties are all excluded from EST.

Consequently, this unfair sales tax system increases tax cascading (Note 1) in the Egyptian economy and decreases the competitiveness of the Egyptian producers even in the Egyptian markets.

On the other hand, VAT laws are generally written in the opposite direction since it states that every transaction of consumption is taxed with VAT except for the exempt and zero-rated sectors clarified in the law. In addition, VAT is considered a powerful tool to eliminate tax cascading and economic distortions in the economy which enables domestic producers to improve their competitive position locally and internationally. The study will discuss these issues clearly in the coming sections.

\subsection{Definition and Design of the (VAT)}

Despite its name, the VAT is usually intended to be a tax on consumption rather than being a tax on value added. VAT was first introduced less than 50 years ago and it remained confined to a handful of countries until the late 1960s.

However, nowadays most countries have a VAT that collects on average around 25 percent of their tax revenues including their compulsory social contributions (Note 2).

In practice, VAT is imposed on all stages of production. However, firms can offset the tax they have paid on their own purchases of goods and services by deducting them from the tax they charge on their sales of goods and services.

To define the VAT base, the VATs observed in practice show diversity with regard to the range of inputs for which the tax refund is available and the range of economic activity to which the tax is applied. For example, some major economies, like China until recently, do not give credits for taxes on capital goods purchases. Most countries zero-rate exports from VAT; but others, as BRO region (Note 3), apply VAT on some exports. Some countries apply VAT only on the manufacturing stage; others exempt services. Practice also varies in how tax offsetting is implemented: by far the use of invoices is the most common method.

Therefore, it is recommended to take the IMF definition for VAT which is: "A broad-based tax levied on commodity sales up to and including, at least, the manufacturing stage, with systematic offsetting of tax charged on commodities purchases as inputs-except perhaps on capital goods-against that due on outputs" (Note 4).

\subsection{The Aim of the Study and Research Questions}

Consequently, the first step in implementing VAT in Egypt is to calculate the VAT base and compare it with the EST revenues collected during the last fiscal year.

On the light of calculating the VAT base in Egypt, the study aims to provide recommendations to the Egyptian government with regard to very important technical issues related to the VAT implementation. For example, what is the best coverage of VAT? What are the items missed in the EST coverage? How should an appropriate small-firm exemption be designed and how should the agricultural sector is treated? Is rate differentiation desired and, if so, should essential commodities be exempted, zero rated or taxed at a lower-than-standard, but positive rate? Is there a case for imposing a higher rate on luxury commodities, or should these perhaps be liable to separate excises? Should the VAT rate be exclusive or inclusive?

\section{Literature Review}

Surveying the literature of introducing VAT in developing countries, we find that (Casanegra, 1986) is considered the most important reference to formulate the frame of VAT in a developing country. It described the principal administrative issues of VAT such as the number of rates used, exempt and zero rated sectors, the treatment of small taxpayers, and Administrative constraints to tax services. Of course, these issues have to be the first step to be discussed before introducing VAT, especially if we are talking about a developing country such as Egypt. This step has to be followed by estimating the VAT base depending on what the VAT system 
should be.

(Casanegra, 1986) was followed by a very important paper (Aguirre \& Shome, 1988) that presented a methodology to calculate the VAT base in Mexico. (Aguirre \& Shome, 1988) developed a methodology that started with production data and modifying them by adjusting for exports, imports, capital transactions, changes in stocks, exemptions, and all intermediate uses (using the input-output table) in order to calculate the taxable consumption.

(Aguirre \& Shome, 1988) opened the road towards dealing with estimating the VAT base more deeply. Consequently, we find (Mackenzie, 1991) constitutes the main reference for estimating the base of VAT in developing countries in general. This paper began with discussing the rationale for VAT exemptions. Then it presented a formula to calculate the VAT base with exemptions. In order to calculate the VAT base with exemptions, (Mackenzie, 1991) made two basic adjustments on the base without exemptions; subtracting the value of sales to consumers of exempt industries and adding the intermediate sales of taxable inputs to exempt industries. Finally, it concludes with deriving the VAT elasticity with exemptions with respect to aggregate consumption. In addition, it discussed how the VAT base can be affected by the technological change. Therefore, the paper tackled several issues which are very important for the Egyptian case.

More development to the techniques used to estimate the VAT base appeared in (Pallechio \& Hill, 1996) that proved the equivalence of the production and consumption methods of calculating the VAT base. Applying these two techniques to Zambia showed that expected VAT revenues are on the range 2-3 percent of GDP for the second half of 1995. In fact, actual VAT revenues collected in this period lay within this range which assured the equivalence of both methods. Due to the limitations of available data, (Pallechio \& Hill, 1996) used approximations to estimate exempt and zero rated categories defined in Zambian VAT law. This will be beneficial to the Egyptian case to perform similar approximations if needed.

Recently, Glenday and Shukla (2001) proved the equivalence of the two methods in treating with the effect of intermediate sales within the exempt goods.

The most recent study that completes the last described effort is (Minh, 2007) that discusses the existing three major approaches for VAT modeling: aggregate national account approach, sector wise national account approach, and input-output (I-O) approach. These three approaches were reviewed extensively in (Jenkins, Kuo, $\&$ Shukla, 2000). The main aim for (Minh, 2007) was to project VAT revenues and to estimate compliance level and tax expenditures in VAT.

In this paper, the target will be to benefit from the papers previously described in introducing VAT in Egypt to replace the current EST. The study will use both the production and consumption methods used in (Pallechio \& Hill, 1996). Then expected VAT revenues will be projected up to the current rates in EST in order to compare it with the actual revenues collected under EST.

The difference will be the expected increase in tax revenues after introducing VAT in Egypt. The study will end up with the proposed structure for VAT system in Egypt.

\section{Method}

Since the Egyptian Ministry of Finance is aiming to introduce VAT in the very near future to replace EST; it is very important for Egyptian policy makers to estimate the expected revenues for VAT. Therefore, this study will calculate the VAT base and VAT revenues to provide advices to the Egyptian policy makers.

For any country, there are two methods used to calculate the VAT base. The first method is called the production method that begins with the GDP in order to get full representation for aggregate value added obtained from production and distribution activities in the economy. Then, deductions are made to subtract imports, exemptions, and zero rating in order to end up with the value added that formulates the VAT base. A clear example for using this method is shown in (Aguirre \& Shome, 1988).

The second method is the consumption method which depends on the fact that VAT is a tax that is levied on the consumption of goods and services in the economy. Consequently, it starts with aggregate final consumption and deducts exemptions and zero ratings of goods and services in order to end up with the VAT base. (Mackenzie 1991) presented a good application for this methodology.

From an academic and theoretical perspective, both methods have to generate the same VAT base. However, this is not true in all cases. (Pallechio \& Hill, 1996) applied both methods for Zambia and they found a difference in the VAT base calculated by each method but they found them equivalent. (Pallechio \& Hill, 1996) attributed this difference to differences in adjustments for intermediate sales that made in each method. 
This study will apply the both methods for Egypt exactly as (Pallechio \& Hill, 1996) did for Zambia. The main targets of applying both production and consumption method for Egypt are investigating the results of each method, testing the equivalence of both methods in Egyptian case, and explaining the sources of difference in results. In addition, the study is aiming to propose the optimal structure of VAT system in Egypt which yields revenues exceeds the current EST revenues and achieves fairness for taxpayers in the Egyptian economy.

\subsection{The Equivalence of Production and Consumption Methods for Calculating the VAT Base in Theory}

The theoretical foundations for both production and consumption methods are almost the same; therefore, they are used to prove the equivalence of these two methods.

As discussed earlier, the production method starts with GDP and then several adjustments would be done for imports, exports, investment expenditure, exemptions, zero rating, and intermediate transactions to calculate the VAT base.

It is recommended for Egypt to apply a system of Consumption-VAT type. Consequently, investment expenditure (I) and exports (X) have to be excluded from the base but imports (M) should be included. In case of no exemptions for any goods and services, hereafter the study will denote goods and services as goods, from the tax, the VAT base (B) would be:

$$
B=G D P-I+M-X
$$

This base described in equation 1 is the same as final consumption $(\mathrm{C})$ :

$$
B=G D P-I+M-X=C
$$

The adjustments that have to be made for the exempted and zero-rated sectors under the VAT system constitute the main differences between the two methods of calculation.

Political concerns always enforce governments to give exemptions under VAT where the tax will not be applied to care about certain necessities such as food and health that are important to low and middle income classes. Other sectors would be exempt because of it is very difficult for the administration to collect the tax imposed on them, SMEs and financial services sectors are clear examples for this case. In case of exemptions, there is no VAT liability on sales and so credit is not given for VAT paid on inputs and intermediate consumption purchased to produce exempt goods. Therefore, exemption from VAT does not mean that the exempted sector does not pay any tax since this sector bears VAT on its inputs.

It is important to describe the total value of sales in the economy in order to enter the impact of exemptions in calculating the VAT base. The value of sales can be:

$$
\text { Total value of sales }=C+I+X+I S
$$

Where (IS) represents intermediate sales.

In case of no exemptions, the tax generated by intermediate sales is offset by the credit taken by purchasers and so intermediate sales drop out of the base. If investment expenditure is treated as an intermediate purchase (of capital goods), which is always the case under a consumption-type VAT, the tax paid on this expenditure is taken as a credit; therefore, I is excluded from the base. Exports, in the standard practice, are zero rated. Then, the VAT base ends with only consumption.

On the other hand, the intermediate purchases of the exempt sectors, as purchases of inputs of taxed goods, have to be included in the VAT base.

Zero-rating refers to a sector or a good that has a zero tax rate in the VAT system which implies a zero tax liability. In this case, credit for VAT paid on inputs purchased by a zero-rated sector is allowed. As a result for the zero VAT liability on sales, the supplier of a zero-rated good has the right to receive a refund for the tax paid on his inputs.

Although both exemption and zero-rating do not impose VAT on sales, input tax credit is only granted under zero-rating which leads the price of the zero-rated good to get rid of the VAT paid on inputs completely. Strictly speaking, this complete removal of VAT from the price of a zero-rated good happens if and only if its supplier does not purchase any inputs from exempt suppliers. Otherwise, any purchase of an exempt input would bear VAT for the price of a zero-rated good to the extent tax is paid on inputs. Consequently, to safeguard the international competitiveness of domestic businesses, exports are usually zero-rated.

Therefore, in calculating the VAT base using the consumption method, the VAT base must not include the intermediate sale of an exempt good. However, the base includes the sale of a taxed good as an input to produce an exempt good since it is considered, under the consumption method, a final sale. 
Therefore, a producer acts as a final consumer because he pays VAT and cannot take a credit because of his exemption. Consequently, under the consumption method, intermediate sales from the taxed sector to exempt sector must be added to final consumption in order to calculate the VAT base.

Under the production method for calculating VAT base, the full value of the exempt input is transferred to the value added of the taxed sector. This implies that; first, the value-added of all exempt goods must be subtracted from the VAT base. Second, the full value of sales of exempt goods to the taxed sectors must be added back to the base. As a result, the VAT base may be larger with exemptions than without as discussed by Zee (1995).

Also, in the production method, GDP includes the value added of the taxed input; therefore, the intermediate sale of taxed goods is not in need to be adjusted. For both the production and consumption method, Intermediate sales within the exempt sector are not included in the VAT base because VAT paid on sales is subtracted as a credit for the purchaser; therefore, it is neither charged nor credited as a consequence of these sales.

Glenday and Shukla (2001) proved the equivalence of the two methods in treating with the effect of intermediate sales within the exempt goods. Using the production method and assuming that only exports are zero-rated, Mackenzie (1991) expressed the VAT base through the following equation;

$B$ production $=G D P-G w-V A$ exempt $+I H-I+I p$, exempt $+M-M$ exempt $-X+X$ exempt $+I S$ exempt ,

$$
\text { taxable }
$$

Where:

VA exempt represents the total value added of exempt domestic production,

G w represents government spending on wages and salaries,

I p,exempt represents investment expenditure of exempt private sectors,

I $\mathrm{H}$ represents residential constructions,

M exempt represents exempt imports,

And $\mathrm{X}$ exempt represents exempt exports.

To avoid double subtracting the exports of exempt goods from the base, exempt exports must be added back to the base. IS exempt,taxable represents the total value of intermediate sales of exempt goods to the taxable sector, which must be added to the base as discussed.

With regard to the consumption method, the formula to calculate the VAT base that is adjusted for consumption of exempt goods and intermediate sales is given by the coming equation;

$$
B \text { consumption }=C-C \text { exempt }+G c+I H+I \text { exempt }+I S \text { taxed,exempt }
$$

Where;

IS taxed,exempt is the intermediate sales of taxed goods to exempt sectors,

C exempt is the exempt final consumption sales,

I exempt is investment expenditures by exempt business whereas I p,exempt above in the production adjustment includes investment goods supplied by exempt producers to other sectors.

Therefore, we can rewrite B production to be;

$$
\begin{gathered}
\text { B production }=G D P-G w-V A \text { final exempt }-(I p-I \text { exempt })+I H-(X-X \text { exempt })+(M-M \text { exempt })+ \\
(I S \text { exempt,taxed }+I \text { exempt,taxed }-V A \text { intermediate exempt }) \\
\text { Noting that } C=(G D P-I+M-X) \text {, this can be reduced to the form; } \\
B \text { production }=C p-C \text { exempt }-G w+I H+I \text { exempt }+I S \text { taxed,exempt }
\end{gathered}
$$

Therefore, from equations 5 and 7 we find that

$$
B \text { production }=B \text { consumption }
$$

Consequently, looking at equations (4) and (7), it is concluded that the study proves the theoretical equivalence between the production and consumption methods of calculating the VAT base using simple mathematical steps that are much easier than the steps discussed by Mackenzie (1991) and Pallechio and Hill (1996).

\subsection{Data Source}

Estimations conducted in this paper are based on the recent social accounting matrix (SAM) 2005 for Egypt and the National Accounts 2006/2007 from the Egyptian Ministry of Planning. In addition, the required data for the 
fiscal year 2006/2007 and other fiscal years is collected from the Financial Monthly issued by the Egyptian Ministry of Finance.

\section{Results}

\subsection{The Production Method-Application to Egypt}

The production method, as described in equation (4), begins with the GDP in order to get full representation for aggregate value added obtained from production and distribution activities in the economy. In Egypt, VAT will be applied to replace EST on imports. Therefore, value of imports has to be added to GDP to reach the base. However, deductions are made to subtract exemptions, and zero rating in order to end up with the value added that formulates the VAT base.

In addition, the paper recommends that Egypt applies a Consumption-VAT type; therefore, credit has to be given to purchases of capital goods and gross domestic capital formation (GDCF) has to be subtracted from the base. Also, exempt sectors will not get refund for their input taxes on capital goods and so their share in GDCF would be added to the base. Government expenditures on wages and salaries have to be subtracted from the base since it is not taxed. Noting that VAT will replace EST, sales tax revenues that is included in GDP has to be subtracted from the base.

The paper recommends the following table (1) for estimating VAT base in Egypt. In this table, the last discussed steps about the production method were done to calculate the VAT base for Egypt using the official published national accounts for the fiscal year 2006/2007. In addition, the paper proposed the following exemptions and assumptions on indicators;

(a) exemptions;

- The only exempt imports are basic food items, aid funded, duty free goods, and diplomatic consumption.

- The only exempt exports are basic food items and all kinds of industrial inputs. These two kinds of exemption were taken to reduce the cost of living for low and middle income classes and to help the Egyptian industry grow.

- For exempt sectors, the study proposed to exempt Basic Food and Non-alcoholic Beverages, Public Health, Agriculture, Transportation (other than air-conditioned buses and railways on high ways), Financial and Insurance Services, production of Recreation and Culture, and consumption of Non-Profit Organizations.

(b) assumptions on indicators;

- Duty free goods, and diplomatic consumption are assumed together to formulate $10 \%$ of total imports.

- $\quad$ For basic food, the official figure for Food and Non-alcoholic Beverages in general is 242.2 billion LE. The study assumed basic food items to be $80 \%$ of this figure which is $=193.76$ billion LE. There was no information about the production inputs and intermediate consumption for this sector; therefore, the study assumed it to be $75 \%$ of the official figure for this sector which is $=181.65$ billion LE.

- For Transportation (other than air-conditioned buses and railways on high ways), the official figure for Transportation in general is 23 billion LE. The study assumed Transportation (other than air-conditioned buses and railways on high ways) to be $50 \%$ of this figure which is $=11.5$ billion LE. Also, there was no information about the production inputs and intermediate consumption for this sector; therefore, the study assumed it to be $75 \%$ of the Transportation (not air-conditioned) sector which is $=8.63$ billion LE.

- The study assumes $90 \%$ of intermediate consumption in Agriculture, Public Health, Financial Services, and Recreation and Culture sectors to be taxable; while, only $75 \%$ of intermediate consumption in NGOs to be taxable.

- $\quad$ The only goods to be zero-rated are exports and capital goods.

- The National Accounts 2006/2007 represents indirect tax revenues $=34.4$ which is equal to revenues of the sales tax on goods and services (31.17) + stamp duty taxes (3.24). Since VAT will only replace the sales tax revenues; therefore, the value of indirect taxes replaced by VAT has to be $=31.17$.

- $\quad$ The study assumed 5\% loss of the resulted base net of exemptions and zero-rating to be considered as a loss from turnover threshold.

- As a loss from non-compliance, the study assumed another $20 \%$ loss of the resulted base net of exemptions and zero-rating. 
Finally, the production method of calculation ended with the estimated VAT base for Egypt to be 342 billion LE. This constitutes around $46 \%$ of GDP, according to the fiscal year 2006/2007 figures, as shown in the coming Table 1.

Table 1. Estimating VAT base in Egypt using production method-billions of Egyptian pounds (LE)

\begin{tabular}{|c|c|c|}
\hline Item & \multicolumn{2}{|l|}{ Value } \\
\hline GDP (market prices) & \multicolumn{2}{|l|}{744.8} \\
\hline Imports + & \multicolumn{2}{|l|}{214.5} \\
\hline Exempt Imports - & \multicolumn{2}{|l|}{32.55} \\
\hline Duty Free Goods and Diplomatic Consumption & \multicolumn{2}{|l|}{21.45} \\
\hline Primary Food Goods for Consumption & \multicolumn{2}{|l|}{3} \\
\hline Processed Food Goods for Consumption & \multicolumn{2}{|l|}{8.1} \\
\hline Exempt Exports + & \multicolumn{2}{|l|}{41.8} \\
\hline Primary Food Goods for Consumption & \multicolumn{2}{|l|}{1.9} \\
\hline Primary Industrial Inputs & \multicolumn{2}{|l|}{2.5} \\
\hline Processed Industrial Inputs & \multicolumn{2}{|l|}{22.4} \\
\hline Raw Fuel and Oil & \multicolumn{2}{|l|}{5.3} \\
\hline Processed Fuel and Other Oils & \multicolumn{2}{|l|}{9.7} \\
\hline Gross Domestic Capital Formation (GDCF) - & \multicolumn{2}{|l|}{152} \\
\hline GDCF in exempt sectors + & \multicolumn{2}{|l|}{19} \\
\hline GDCF in Financial Sector & \multicolumn{2}{|l|}{2.1} \\
\hline GDCF in NGOs & \multicolumn{2}{|l|}{0.6} \\
\hline GDCF in Agriculture & \multicolumn{2}{|l|}{5.4} \\
\hline GDCF in Transportation & \multicolumn{2}{|l|}{10.8} \\
\hline GDCF in Public Health & \multicolumn{2}{|l|}{0.1} \\
\hline Government Wages and Salaries - & 64.2 & 64.2 \\
\hline Indirect Tax Revenues (replaced by VAT) - & 31.17 & 31.17 \\
\hline Exempt Sectors & \multicolumn{2}{|c|}{ Output -Production Inputs and Intermediate Consumption +} \\
\hline Basic Food and Non-Alcoholic Beverages & 193.76 & 181.65 \\
\hline Public Health & 2.1 & 1.44 \\
\hline Agriculture & 130.1 & 26.01 \\
\hline Transportation (other than airconditioned buses and railway) & 11.5 & 8.63 \\
\hline Financial and Insurance Services & 33.98 & 6.318 \\
\hline Recreation and Culture & 19.4 & 9 \\
\hline Non- Profit Organizations & 6.4 & 3.375 \\
\hline Total & 397.24 & 236.42 \\
\hline \multicolumn{3}{|l|}{ Zero-rated Sectors } \\
\hline Exports - & \multicolumn{2}{|l|}{123.3} \\
\hline VAT base net of exemptions and zero-rating & \multicolumn{2}{|l|}{456.06} \\
\hline Loss from turnover threshold ( $5 \%)-$ & \multicolumn{2}{|l|}{22.80} \\
\hline Loss from non-compliance $(20 \%)-$ & \multicolumn{2}{|l|}{91.21} \\
\hline Final Estimated VAT Base & \multicolumn{2}{|l|}{342.04} \\
\hline VAT Base as $\%$ of GDP & \multicolumn{2}{|l|}{$46 \%$} \\
\hline
\end{tabular}

Source: Egyptian Ministry of Finance, (SAM) 2005 for Egypt; and author's calculations.

\subsection{The Consumption Method-Application to Egypt}

The consumption method, as discussed in equation (5), uses the final consumption of private and public sectors and adjusts them to the exempt consumption and taxable exempt intermediate sales. These calculations are described in details through the coming table (2). 
Table 2. Estimating VAT base in Egypt using consumption method - billions of Egyptian pounds (LE)

\begin{tabular}{|c|c|c|}
\hline Item & Value & \\
\hline Private Final Consumption Expenditure & 539.2 & \\
\hline Government Final Consumption Expenditure (net of Wages) & 84.4 & \\
\hline Gross Domestic Capital Formation (GDCF) in exempt sectors + & 32.9 & \\
\hline GDCF in Financial Sector & 2.1 & \\
\hline GDCF in NGOs & 0.6 & \\
\hline GDCF in Agriculture & 5.4 & \\
\hline GDCF in Building and Construction & 2.4 & \\
\hline GDCF in Transportation & 10.8 & \\
\hline GDCF in Property Services & 11.5 & \\
\hline GDCF in Public Health & 0.1 & \\
\hline Indirect Tax Revenues (replaced by VAT) - & 31.17 & 31.17 \\
\hline Exempt Sectors & Output - & $\begin{array}{l}\text { Production Inputs and } \\
\text { Intermediate Consumption }+\end{array}$ \\
\hline Basic Food and Non-Alcoholic Beverages & 174.384 & 130.8 \\
\hline Public Health & 2.1 & 1.44 \\
\hline Agriculture & 97.575 & 26.01 \\
\hline Transportation (other than airconditioned buses and railway) & 10.925 & 8.19 \\
\hline Financial and Insurance Services & 30.582 & 6.318 \\
\hline Recreation and Culture & 15.52 & 9 \\
\hline Non- Profit Organizations & 6.08 & 3.375 \\
\hline Total & 337.166 & 185.14 \\
\hline VAT base net of exemptions and zero-rating & 473.30 & \\
\hline Loss from turnover threshold $(5 \%)-$ & 23.67 & \\
\hline Loss from non-compliance (20\%) - & 94.66 & \\
\hline Final Estimated VAT Base & 354.98 & \\
\hline VAT Base as $\%$ of GDP & $48 \%$ & \\
\hline
\end{tabular}

Source: Egyptian Ministry of Finance, (SAM) 2005 for Egypt; and author's calculations.

Using the same assumptions applied in the production method, the consumption method added only one new assumption that exempt expenditure $=$ the percentage of output of exempt sectors that the household sector consumes.

This new assumption means that exports, investment, and intermediate sales have to be excluded from the values of exempt sectors' output. To calculate the shares of household consumption in the output of exempt sectors, the study used the recent (SAM) 2005 for Egypt. Then, the study used the National Accounts 2006/2007 to get the required data for the fiscal year 2006/2007 assuming that these shares did not change.

Calculations showed that these shares are; $90 \%$ for basic food and non-alcoholic beverages, $100 \%$ for public health, $75 \%$ for agriculture, $95 \%$ for transportation, $90 \%$ for financial and insurance services, $80 \%$ for recreation and culture, and $95 \%$ for NGOs.

Finally, the consumption method estimated the VAT base for Egypt to be 354.98 billion LE which constitutes around $48 \%$ of GDP as shown in the last Table 2.

\section{Discussion}

\subsection{Some Technical Policy Recommendations to Egyptian Policymakers in Designing VAT}

The best choice for Egypt would be applying the consumption-type VAT based on the destination principle. This type of VAT gives incentive to more savings in the economy since it is a tax on consumption. Consequently, it can be considered an engine for economic growth. A destination-based VAT is a tax on consumption but origin-based VAT is a tax on production (Ebrill et al., 2001). The study recommends a destination-based VAT to be more appropriate than origin-based VAT in the Egyptian case.

On the other hand, under the product-type VAT there is no refund for taxes imposed on investment goods. Also, under an income-type VAT the refund is only allowed for taxes on the depreciated part of capital. Therefore, these two types of VAT are taxing investments which impede capital accumulations required for economic growth. 
With regard to VAT rates, there are several scenarios;

Under any scenario, exports would be zero rated and a list of exempt sectors as shown in tables 1 and 2 would appear in the VAT law.

The first scenario is to apply only one rate for all goods and services in all taxed sectors in order to reduce price distortions to its minimum level. Therefore, tables 1, 2, A, C, and F that are attached to the EST law would be removed under this scenario. Consequently, this scenario increases the administration costs as a result for changing the tax rate structure. Compliance costs also will increase since the old taxed sectors have to recalculate their liabilities under the new taxing system. However, this scenario gives us the best economic efficiency under the VAT system.

The second one is to maintain the same rate structure as it is under the EST system which means keeping tables 1, 2, A, C, and F to be the same under the VAT system. Some small changes can be entered to these old tables such as raising the tax rate on air conditioned means of transportation between Governorates (buses, railway), the services of fixed phones, local telegram to the public, government cabins ... etc, other than mobile phones, and artistic agent services in public and private parties from $5 \%$ to the standard rate $10 \%$. It seems that there is no reason to tax these activities with a small rate. This scenario does not cause any increase in either administrative or compliance costs. In addition, tax revenues will increase paving the way towards achieving a significant reduction in the budget deficit.

The third scenario is the same as the second one but with lowering the standard rate from $10 \%$ to $8 \%$ which implies $20 \%$ decrease in the tax rate. Compared to revenues collected under EST, the study expects revenues may not be sharply affected under this scenario. The reason for this is that the reduction in revenues because of reducing the tax rate will be offset by the revenues increase due to widening the base and reduction in non-compliance. Applying 8\% VAT rate would yield around 28 billion LE as expected VAT revenues but we can add at least another 1 to 2 billion LE as additional revenues from goods taxed at $15 \%$ and $25 \%$ rates. Consequently, tax revenues will be hardly affected by this significant reduction in the tax rate.

Therefore, the study recommends applying this last scenario since it enables the government to achieve economic and social stability, popular gains, and political support needed to complete the required reforms in the tax system. Reducing the VAT standard rate to become $8 \%$, instead of $10 \%$ standard rate under EST, would give the Egyptian Ministry of Finance a political support to implement VAT.

To compute VAT liabilities, it is better to use the invoice credit method. As (Ebrill et al., 2001) stated "practice and consensus heavily favors the invoice credit method". In practice, there is no application for broad-based national VAT using the addition method. The invoice method is more suitable for using differential rate structures. Egypt is applying invoice method in the EST system; therefore, tax administration is well prepared to this method under VAT. In addition, the invoice method seems to be consistent with the destination-based VAT recommended for Egypt. Moreover, invoices can easily be cross-checked to discover any overestimation of credit entitlement which discourages fraudulent undervaluation of intermediate sales.

With regard to the level of threshold, the study recommends to raise the lower bound of mandatory registration in the VAT system. The new level must be determined up to statistics about the revenues collected from small taxpayers and their administration costs using cost-benefit analysis. The optimal threshold level is determined when revenues collected exceed costs of administrating such a level of annual turnover. In addition, it is recommended for the Egyptian Ministry of Finance to give the right for voluntary registration to traders and industries that have an annual turnover level lower than 500,000 LE. For services providers such as lawyers, doctors, dentists, etc registration has to be obligatory.

Finally, the last policy recommendation advised by the study to the Egyptian Ministry of Finance is about the time to enact the new expected VAT law. The study recommends the new VAT law to start in July 2014.

By this date, the Egyptian Ministry of Finance has plenty of time to prepare the law draft and discuss it with the interest groups, such as the High Council for Taxes and the Egyptian Association for Taxes, to take their comments in consideration before the issuance of the final version. Then, the law has to be ratified from the Egyptian Parliament.

Also, several reforms are needed in tax administration to be prepared for VAT. For example, activating the auditing and inspecting functions through coordinating the cross checking mechanism with the income tax and customs departments. Moreover, media campaign is needed to inform people with VAT.

In addition, this long time of preparation will give the chance to the Egyptian economy to recover after the shock it has received in the aftermath of the recent global financial crisis and political instability. Positive signs of this 
recovery are expected to appear by the end of 2014 which would give the incentive towards accelerating the new VAT law implementation in Egypt.

\section{Conclusion}

It is clear that the estimations for the VAT base are much closed from both production and consumption method. The difference between both methods is only 12.94 billion LE which is $=1.7$ percent of GDP in the fiscal year 2006/2007 which may be attributed to the informal sector activities and tax evasion. This difference can be considered negligible especially if we compare it with the difference appeared in the study by Pallechio and Hill (1996) that estimated this difference for Zambia to reach 10 percent.

The study states that it is reasonable, significant, and desirable estimations for VAT base in Egypt since if we apply a VAT rate $=10 \%$, which is equal to the current EST rate for most of commodities, on this base, the estimated VAT revenues will be $=34.2$ billion LE under the production method and 35.5 billion LE under the consumption method. This estimated VAT revenues are much closed to the actual EST revenues in 2006/2007 which was 31.2 billion LE. Consequently, replacing VAT instead of EST in Egypt will reduce economic distortions and increase tax revenues at the same time. Therefore, the Egyptian economy is in need for this replacement process in the near future.

In addition, the expected VAT revenues that would be at least 34.2 billion LE $=4.6$ percent of GDP in the fiscal year 2006/2007. In early 2000, the ratio of VAT revenues as a percentage of GDP was 3.9 for Sub-Saharan Africa, 4.9 for Americas, 5.1 as an average for world blocks, 5.7 for North Africa and Middle East, and 6.4 for Central Europe and BRO (Note 5).

Therefore, it implies that the Egyptian ratio lies within the international range with an acceptable burden on the Egyptian society. This can be illustrated clearly in the following table (Note 6);

Table 3. VAT Features by region ratios (in percent)

\begin{tabular}{lcc}
\hline & Standard Rate & VAT Revenues as \% of GDP \\
\hline Asia and Pacific & 10.4 & 3.3 \\
Sub-Saharan Africa & 16 & 3.9 \\
Egypt & 10 & 4.6 \\
Small Islands & 16.1 & 4.7 \\
Americas & 13.5 & 4.9 \\
Average & 16 & 5.1 \\
North Africa and Middle East & 15.7 & 5.7 \\
Central Europe and BRO & 20.1 & 6.4 \\
EU (plus Norway and Switzerland) & 18.8 & 7 \\
\hline
\end{tabular}

Source: Ebril et al. (2001). The Modern VAT, International Monetary Fund; and author's calculation for Egypt.

Also, the VAT-efficiency indicators seem healthy with this expected VAT revenue as shown in the following table (4) (Note 7). The table explains the Egyptian position with regard to Efficiency Ratio (the ratio of VAT revenues to GDP divided by the VAT standard ratio) and C-Efficiency Ratio (the ratio of VAT revenues to final consumption, instead of GDP, divided by the VAT standard ratio). The lower these ratios are; the higher tax evasion and more exemptions are there in the VAT system. Since it is recommended for Egypt to apply Consumption-type VAT, table (4) is sorted ascending according to C-Efficiency Ratio.

Table 4. VAT efficiency ratios (in percent)

\begin{tabular}{lcc}
\hline & Standard Rate & VAT Revenues as \% of GDP \\
\hline Sub-Saharan Africa & 27 & 38 \\
Americas & 37 & 57 \\
North Africa and Middle East & 37 & 57 \\
Egypt & 46 & 57 \\
Asia and Pacific & 35 & 58 \\
Central Europe and BRO & 36 & 62 \\
EU (plus Norway and Switzerland) & 38 & 64 \\
Small Islands & 48 & 83 \\
\hline
\end{tabular}

Source: Ebril et al. 2001. The Modern VAT, International Monetary Fund; and author's calculation for Egypt. 
With regard to tax evasion, it can be concluded that EST revenues suffer from a loss reaches around 13.7 billion LE in 2006/2007 as a matter of tax evasion. This conclusion can easily be reached by applying the $10 \%$ EST standard rate to the VAT base, under consumption method, before excluding the $20 \%$ non-compliance ratio which is $=449.64$ billion LE. Consequently, the expected revenues for EST would equal to at least 44.9 billion LE. However, EST actual revenues are only 31.2 billion LE. Therefore, the difference $=13.7$ billion LE can be considered the value of tax evasion in the EST system.

\section{References}

Aguirre, C. A., \& Parthasarathi, S. (1988). The Mexican Value-Added Tax (VAT): Methodology for Calculating the Base. National Tax Journal, XLI(4), 543-554. Retrieved from http://ntj.tax.org/wwtax/ntjrec.nsf/175d710dffc186a385256a31007cb40f/ca865cc5aeea982c8525686c00686 d91/\$FILE/v41n4543.pdf

Barham, V., Poddar, S. N., \& Whalley, J. (1987). The Tax Treatment of Insurance under a Consumption Type, Destination Based VAT. National Tax Journal, 40(2), 171-82. Retrieved from http://www.jstor.org/discover/10.2307/41788655?uid=2129\&uid=2\&uid=70\&uid=4\&sid=21103674432497

Bird, M. (1987). A New Look at Indirect Taxation in Developing Countries. World Development, 15(9), 11511161. http://dx.doi.org/10.1016/0305-750X(87)90184-7

Cnossen, S. (1989). What Rate Structure for a Goods and Services Tax? Canadian Tax Journal, 37(5), 11671181.

De Jantscher, M., \& Casanegra. (1986). Problems of Administering a Value-Added Tax in Developing Countries. IMF Working Paper, WP/86/15. Retrieved from http://papers.ssrn.com/sol3/papers.cfm?abstract_id=884603

Ebrill, L., Michael, K., Bodin, J. P., \& Summers, V. (2001). The Modern VAT. International Monetary Fund, Washington, D.C.

Glenday, G., \& Shukla, G. P. (2001). Tax Analysis and Revenue Forecasting: Issues and Techniques. Duke Center for International Development, Duke University, Durham, NC, USA.

Heller, P. S. (1981). Testing the Impact of Value-Added and Global Income Tax Regimes on Korean Tax Incidence: An Input-Output and Sensitivity Analysis. International Monetary Fund, 28(2), 375-410. http://dx.doi.org/10.2307/3866935

Hicks, L., \& Lee, H. (1997). The Impact of Fiscal Policies on the Poor in Guatemala. Journal of Public Budgeting, Accounting, and Financial Management, 9(Fall), 501-515. Retrieved from http://www.pracademics.com/jpbafm/download/Vol9/issue-3/HICKS.pdf

James, A., Bahl, R., \& Murray, M. (1991). Tax Base Erosion in Developing Countries. Economic Development and Cultural Change, 39(4), 849-872. http://dx.doi.org/10.1086/451912

Kay, J. A., \& Davis, H. (1990). The VAT and Services. In G. Malcolm, C. S. Shoup \& G. P. Sicat (Eds.), Value Added Taxation in Developing Countries: A World Bank Symposium (Chap. 6). The World Bank, Washington, D.C.

Keen, M., \& Mintz, J. (2004). The Optimal Threshold for a Value-Added Tax. Journal of Public Economics, 88(3-4), 559-576. http://dx.doi.org/10.1016/S0047-2727(02)00165-2

Mackenzie, G. A. (1991). Estimating the Base of the Value-Added Tax (VAT) in Developing Countries: The Problem of Exemptions. IMF Working Paper, WP 91/21. http://dx.doi.org/10.5089/9781451921465.001

Minh, L. (2007). Estimating the VAT Base: Method and Application. Tax Notes International, 46(2), 203-210. Retrieved from http://siteresources.worldbank.org/INTTPA/Resources/46TI0203-Le.pdf

Newbery, D., \& Stern, N. (1987). The Theory of Taxation for Developing Countries. International Bank for Reconstruction and Development, Washington, D.C.

Pellechio, J., \& Hill, C. (1996). Equivalence of the Production and Consumption Methods of Calculating the Value-Added Tax Base: Application in Zambia. IMF Working Paper, WP 96/67, 1-22. Retrieved from http://www.imf.org/external/pubs/ft/wp/wp9667.pdf

Perkins, D., Steven, R., David, L., \& Steven, A. (2012). Economics of Development (7th ed.). New York: Norton and Company Inc.

Schenk, A., \& Oldman, O. (2007). Value Added Tax: A Comparative Approach. Cambridge University Press. http://dx.doi.org/10.1017/CBO9780511618048 
Tait, A. (1988). Value Added Tax: International Practice and Problems. International Monetary Fund, Washington, D.C.

Zee, H. (1995). Value-Added Tax. In S. Parthasarathi (Ed.), Tax Policy Handbook, Fiscal Affairs Department. International Monetary Fund, Washington, D.C.

Zee, H. (2005). Simple analytics of setting the optimal VAT exemption threshold. De Economist, 153(4), 461471. http://dx.doi.org/10.1007/s10645-005-2662-8

\section{Notes}

Note 1. Tax Cascading means to impose tax on tax since there is no tax credit for inputs which increases the burdens on producers.

Note 2. Ebril et al. 2001. The Modern VAT, International Monetary Fund.

Note 3. The Baltic countries are Russia, and other countries of the former Soviet Union.

Note 4. Ebril et al. 2001. The Modern VAT, International Monetary Fund, page 2.

Note 5. Ibid, page 13.

Note 6. Ibid and the researcher calculations for Egypt.

Note 7. Ibid and the researcher calculations for Egypt.

\section{Copyrights}

Copyright for this article is retained by the author(s), with first publication rights granted to the journal.

This is an open-access article distributed under the terms and conditions of the Creative Commons Attribution license (http://creativecommons.org/licenses/by/3.0/). 